\title{
NORTRIPTYLINE IN ENURESIS IN CHILDREN WITH SPECIFIC GAS-CHROMATOGRAPHIC DETERMINATION OF STEADY-STATE SERUM LEVELS
}

\author{
Colonel T. B. STEPHENS, M.B., M.R.C.P.E., F.R.C.Psych., L/R.A.M.C. \\ Royal Army Medical College, Millbank
}

\section{Introduction}

NoCTURNAL enuresis is a common symptom, being estimated by Meadow (1970) to affect 400,000 children between the ages of 4 and 10 in the United Kingdom alone.

Since MacLean's (1960) original report, the tricyclic anti-depressant drugs have been studied extensively in the treatment of nocturnal enuresis. Most authors have found them beneficial, including Mariuz and Walters (1963), Treffert (1964), Noack (1964), Alderton (1965), Ice, Daus and Smith (1966), Yodfat (1966), Thomsen, Reid and Hebeler (1967), Agarwala and Heycock (1968) and Milner and Hills (1968) who used imipramine and Smith and Gonzales (1967) and Lake (1968), who used nortriptyline, but complete control has been unusual and some, including Fisher et al (1963) and Abrams.(1964) have found placebos as useful: Maxwell and Seldrup (1971) conducted a double blind trail with imipramine, using doses up to $50 \mathrm{mg}$, and concluded that the benefits of the drug were so well established that they would not hesitate to use it as a treatment. They found imipramine to be significantly superior to placebo in reducing the number of "wet" nights. Forsythe and Merrett (1969) comparing imipramine and nortriptyline with a placebo, found similar benefit.

Dische (1971) has found that 38 per cent of enuretic children from Southwark, London become dry on simple advice and encouragement alone and that the proportion was raised to 93.7 per cent if a buzzer was used for those who did not respond. She acknowledged that a safe reliable drug would be valuable but thought that the antidepressant drugs did not fill this need, being less effective than encouragement. Review articles by Young (1969) and Meadow (1970) are also unfavourable to drugs and favour electric alarms, but experience suggests that considerable trouble and enthusiasm are necessary to keep such apparatuses in use and that in normal clinical practice they are often abandoned before benefit has been obtained. The possibility of improving the results with simple drug treatment is, therefore, attractive.

It is not clear that, in the trials quoted, the drugs used had been administered in properly selected doses. The use of tricyclic drugs has been studied more closely in relation to depression and the results of detailed work on the pharmacology and metabolism are available. Nortriptyline is the desmethylated metabolite of amitriptyline and like its parent drug is useful in certain cases of depression, where work by Asberg et al (1971) has shown correlations between its clinical effects and serum levels while Alexanderson, Price Evans and Sjoqvist (1969) have shown a marked genetically determined variation in serum levels between patients, Hammer, Idestrom and Sjoqvist (1967) have shown a 36-fold variation between the lowest and highest steady-state plasma level of the drug given in constant dosage to depressed adults. They state that intestinal absorption is virtually complete and that urinary excretion is negligible so that the wide range in steady-state plasma levels probably indicates large individual differences in hydroxy- 
lating enzymes between patients. They suggest that phenobarbitone given concurrently can reduce the plasma level (Hammer, Idestrom and Sjoqvist 1967) and that patients who metabolise the drug rapidly have a low plasma level and are resistant to treatment while those with a slow metabolism would be prone to toxic effects. A relationship between favourable outcome in depression and high steady-state plasma levels has been shown with imipramine by Walter (1971).

It was decided to determine whether the use of nortriptyline in doses related to body size and to actual blood levels obtained would influence the response in children who do not improve with standard doses and might be insensitive to the drug by reason of rapid hydroxylation of it. It was supposed that if this were the case, toxic effects would not be increased in those requiring higher doses, nor would the serum levels obtained be significantly higher in relation to dose per kilogram body weight. In view of the work of Asberg et al (1971) who showed a therapeutic range of depression between $50-139 \mathrm{ng}$ nortriptyline $/ \mathrm{ml}$ plasma $(\mathrm{ng} / \mathrm{ml})$ it was expected that serum levels of the order of $100 \mathrm{ng} / \mathrm{ml}$ would be required.

\section{Patients and methods}

The fact that the subjects of this study were the children of services families living in Germany required that the study of each child should be completed as quickly as possible, by keeping intervals between review short and accepting correspondingly short periods of assessment of response. The assumed time for stabilization of serum level of nortriptyline on steady dosage of two weeks suggested these intervals. Difficulties were also foreseen because the assays of nortriptyline levels were to be carried out in London and this, combined with reluctance to perform repeated venepuncture on quite small children, dictated a reduction in chromatographic assessment to a minimum. The trial was therefore uncontrolled and it was decided to start treatment in each case with a standard $10 \mathrm{mg}$ dose of nortriptyline by mouth in the form of Allegron tablets and to increase gradually to an arbitrary upper dose limit of $3 \mathrm{mg} / \mathrm{kg}$ body weight $/ 24$ hours $(\mathrm{mg} / \mathrm{kg} / 24$ hours), and to take blood only after a result had been obtained.

In view of the fact that relatively large doses, even of a "safe" drug like nortriptyline were expected to be used in children who were suffering from a mere symptom which presents itself as a nuisance to the parents, special attention was required to the problem of toxicity. Complaints of toxic effects were solicited at every review by presenting the parents, rather than the child, with a list of previously described toxic symptoms and inviting response and this, too, would be expected to interfere with a double blind technique. Nevertheless, the known common mild toxic effects of tricyclic drugs were not taken to necessarily indicate immediate stopping of treatment:

Unfortunately, in the event, complaints of toxicity turned out to be very common but the design prevents any correlation of them with serum levels of the drug; crude dosage and dosage in relation to body weight only being available for study.

Sixty-three children of British servicemen or associated civilian families living in West Germany were studied. They were between 5 and 16 years of age, not suffering from fits, diabetes mellitus or any obvious neurological disorder and enuretic by the mother's statement for at least an average of 5 nights per week for at least the past year. Enuresis was taken to mean nocturnal incontinence of urine with or without daytime frequency or incontinence and both primary and secondary enuretics were accepted. 
Preliminary examination was undertaken to establish the type and severity of enuresis, the presence or absence of a family history and to exclude obvious physical causes. An initial electrocardiogram (E.C.G.) was taken and treatment then commenced with nortriptyline (Allegron) $10 \mathrm{mg}$ o.n.

At the outset, parents were told that enuresis is a common complaint for which the child is not responsible and that no amount of reward or punishment can influence its frequency. They were told, as tactfully as possible that, however understandable it may be, irritation should not be expressed and the child should neither be punished for a wet bed nor rewarded for a dry one; in short, that the enuresis should be ignored as far as possible. Service people are traditionally seen as punitive disciplinarians in their dealings with their children but there were few instances where overt punishment was admitted though there was a proportion where a parent, usually the father, asked whether the ' habit' was not due to 'laziness'. They were advised that restriction of fluids and ' lifting' are of doubtful value but that they should continue their former practices during the course of treatment. Mothers were instructed to encourage micturition immediately before retiring and then to give the tablets. A "dry. bed" chart was given on each occasion with the current date and the date and time of the next appointment marked on it, the number of tablets required for this period were then dispensed. The parents were asked to fill in the "dry bed" chart themselves without arousing the interest of the child in it.

The patients were seen for a second time after one month on the minimum dose. Thereafter they were seen at intervals of 2 weeks. The parents were questioned about possible toxic effects, treatment was adjusted and new charts and supply of the drug were issued. In view of a number of references to cardiac irregularities associated with tricyclic drugs, especially at high dosage (Kristiansen 1961, Giles 1963, Connelly and Venables 1961, Kelly, Fay and Laverty 1963, Brackenridge, Peters and Watson 1968), E.C.G's were also performed at each visit and particular attention was paid to P-R intervals, heart rate and to inversion of $T$ waves. Dosage was increased to $25 \mathrm{mg}$ o.n., to $35 \mathrm{mg}$ o.n., to $50 \mathrm{mg}$ o.n., and thereafter by $25 \mathrm{mg}$ o.n. to a maximum of $3 \mathrm{mg} / \mathrm{kg} / 24$ hours, or until complete continence for 2 weeks was achieved. If toxic effects occurred the treatment was reconsidered and stopped if indicated. In any of these events, blood was taken for nortriptyline estimation. In patients who reached the arbitrary limit without achieving continence or developing toxic effects, plasma nortriptyline was estimated and a new maximum calculated on the basis of $100 \mathrm{ng} / \mathrm{ml}$ in serum. This second level was approached by gradual increase in dosage with the same precautions. No child received perphenazine, Halo-peridol or chlorpromazine which are thought to influence nortriptyline metabolism (Gram and Over 1972) nor any barbiturates, benzodiazepines, methaqualone, or diphenylhydantoin which are inducers of hepatic drugmetabolising enzymes (Stevenson et al 1972).

Serum estimations were performed by the specific gas-chromatographic method of Braithwaite and Widdop (1971). This method has a lower limit of sensitivity of $20 \mathrm{ng} / \mathrm{ml}$ and has shown plasma levels varying between $20 \mathrm{ng} / \mathrm{ml}$ in adults receiving doses of the order of $150 \mathrm{mg}$ nortriptyline daily.

Ten $\mathrm{ml}$ of blood were taken into a lithium/heparin bottle by venepuncture between 
9 a.m. and 10 a.m., the child having been receiving a steady dose of the drug nightly for at least 2 weeks. The blood was separated immediately at $3000 \mathrm{rev} / \mathrm{min}$ for 5 minutes and both fractions were frozen and stored at minus $5^{\circ} \mathrm{C}$ while awaiting transport to the United Kingdom by air in insulated iced containers. Stability studies (Braithwaite and Widdop) have failed to detect any deterioration in drug content after incubation for 70 hours at $37^{\circ} \mathrm{C}$ and in most cases the transfer of the blood was effected in about that time. On occasion it was longer and one specimen was in cold storage for 3 weeks.

\section{Results}

There were 35 boys and 28 girls, none of whom had any known relevant physical disorder but 60 had a known family history, taking that to mean enuresis as already defined, in parents, siblings or either pair of grandparents. Forty-four of the children had probably had previous treatment with tricyclic drugs of one sort or another usually in doses of $5 \mathrm{mg}$ to $25 \mathrm{mg}$ nightly. The average age of the children was 7 years 6 months with a minimum of 5 years and a maximum of 15 years. They weighed between $13 \mathrm{~kg}$ and $50 \mathrm{~kg}$ with an average of $24.2 \mathrm{~kg}$. Fourteen boys and 14 girls became dry, a total of 28 (44.4 per cent) (Table I). The standard taken was 2 weeks of continence while

Table I

Number of children becoming dry by ages

\begin{tabular}{l|r|r|r|r|r|r|r|r|r|r|r|c}
\hline Age (years) & 5 & 6 & 7 & 8 & 9 & 10 & 11 & 12 & 13 & 14 & 15 & Total \\
\hline Number in cohort & 13 & 14 & 10 & 9 & 4 & 5 & 4 & 2 & 1 & - & 1 & 63 \\
\hline Number dry & 4 & 9 & 1 & 7 & 3 & - & 2 & 1 & 1 & - & - & 28 \\
\hline
\end{tabular}

Notes: There is no significant deviation from the mean in these figures (mean age of all children $=7.51$. Mean age of those achieving continence $7.54+-0.06$ ).

continuing to receive treatment. This is a short time but was chosen as a compromise between mere reduction in frequency which was regarded as of little real value to the patient and an impractically high standard of complete continence for a longer period. If one takes the standard of wetting no more than one third as often, the total improved was 47 or 74 per cent. Twenty-one ( 46 per cent) primary enuretics out of 46 became dry while (41 per cent) out of 17 secondary enuretics did so, an insignificant difference.

Table II shows that most of the children who became continent did so on doses above $25 \mathrm{mg}$ and less than $100 \mathrm{mg}$. If the results within this dose range are compared with those outside it, the difference is significant at the level of $\mathrm{P}=0.02$ when only those children receiving a maximum dose are considered and at the level of $P<0.01$ when all children who received doses within the range are taken.

Table III shows the relationship between dose per $\mathrm{kg}$ and outcome. A significantly greater proportion of those children achieving dose/weight ratios between $1.5 \mathrm{mg} / \mathrm{kg}$ body weight $(\mathrm{mg} / \mathrm{kg})$ and $3.5 \mathrm{mg} / \mathrm{kg}$ became continent $(\mathrm{P}<0.01)$.

Table IV shows the blood levels of nortriptyline attained against the outcome of treatment. In certain cases more than one blood level was obtained and in these the higher level has been recorded in the table. Unfortunately, a total of 14 children either did not have blood taken at all or the test was defective in some way so the results are missing. The remaining figures show that continence was acquired in most of the successful cases between blood levels of $25 \mathrm{ng} / \mathrm{ml}$ and $150 \mathrm{ng} / \mathrm{ml}$ but the difference between 
these and those not achieving continence at that level is significant only at the level of $P<0.05$. This was in spite of the fact that blood was taken in the successful cases always because of the success and in the others for various reasons including toxicity, reaching an arbitrary maximum dosage and reaching a calculated arbitrary maximum blood level.

Table II

Relationship between number of children becoming dry and dose range

\begin{tabular}{l|c|c|c}
\hline Dose in $\mathrm{mg}$ & Total number receiving & Number receiving as maximum & Number becoming dry \\
\hline Up to 24 & 63 & 4 & 2 \\
\hline 25 to 49 & 59 & 9 & 7 \\
\hline 50 to 74 & 50 & 16 & 7 \\
\hline 75 to 99 & 34 & 16 & 8 \\
\hline 100 to 124 & 18 & 10 & 2 \\
\hline 125 to 149 & 8 & 6 & 2 \\
\hline 150 to 174 & 2 & 2 & - \\
\hline Totals & 234 & 63 & 28 \\
\hline
\end{tabular}

Table III

Relationship between dose per $\mathrm{kg}$ body weight and outcome

\begin{tabular}{l|c|c|c}
\hline $\begin{array}{c}\text { Dose/weight ratio } \\
\text { in } \mathrm{mg} / \mathrm{kg}\end{array}$ & Number at risk & Number reaching maximum dose & Number becoming dry \\
\hline Up to 0.49 & 63 & 3 & 2 \\
\hline 0.5 to 0.99 & 60 & 2 & - \\
\hline 1.0 to 1.49 & 58 & 2 & 2 \\
\hline 1.5 to 1.99 & 56 & 7 & 5 \\
\hline 2.0 to 2.49 & 49 & 3 & 3 \\
\hline 2.5 to 2.99 & 46 & 10 & 3 \\
\hline 3.0 to 3.49 & 36 & 24 & 10 \\
\hline 3.5 to 3.99 & 12 & 4 & - \\
\hline 4.0 to 4.49 & 8 & 2 & - \\
\hline 4.5 to 4.99 & 6 & 2 & - \\
\hline 5.0 to 5.49 & 4 & 1 & - \\
\hline 5.5 to 5.99 & 3 & 2 & - \\
\hline 6.0 to 6.49 & 1 & - & - \\
\hline 6.5 to 6.99 & 1 & - & - \\
\hline 7.0 to 7.49 & 1 & - & - \\
\hline 7.5 to 7.99 & 1 & & \\
\hline Totals & 405 & & \\
\hline
\end{tabular}


Table IV

Blood levels of nortriptyline attained against the outcome of treatment

\begin{tabular}{l|c|c|c}
\hline $\begin{array}{c}\text { Blood level in } \\
\text { ng/ml }\end{array}$ & $\begin{array}{c}\text { Number becoming } \\
\text { continent }\end{array}$ & $\begin{array}{c}\text { Number reaching level } \\
\text { without continence }\end{array}$ & Totals \\
\hline Up to 24 & -2 & 2 \\
\hline 25 to 49 & 4 & 5 & 9 \\
\hline 50 to 74 & 2 & 2 & 4 \\
\hline 75 to 99 & 8 & 3 & 11 \\
\hline 100 to 124 & 4 & 1 & 5 \\
\hline 125 to 149 & 3 & 1 & 4 \\
\hline 150 to 174 & 2 & 6 & 8 \\
\hline 175 to 199 & 1 & 1 & 2 \\
\hline 200 to 224 & - & 2 & 2 \\
\hline 225 to 249 & - & - & 1 \\
\hline 250 to 274 & 1 & - & 14 \\
\hline 275 to 299 & - & - & 63 \\
\hline 300 to 324 & - & 35 & 1 \\
\hline Unknown & 3 & & \\
\hline Totals & 28 & & \\
\hline
\end{tabular}

Toxic effects. were recorded 64 times in 39 (62 per cent) of the patients (Table V), which also shows the relevant doses, maximum doses reached by all the children and the relationship between the occurrence of toxic effects and the outcome of treatment, which is not significant. Treatment was discontinued before the therapeutic outcome had been decided in a total of 4 cases. Patient 2 stopped because of nightmares which are undoubtedly related to the treatment. Patient 54 stopped at the mother's request because of a rash which was thought to be rubella but occurred so inopportunely as to cause the mother to refuse to continue. Patients 20 and 58 failed follow-up for unknown reasons. It was remarkable, considering the notorious turbulence of Service life that no patients failed to complete the trial through posting though several only just did so in spite of the intervals between assessments and dose changes having been kept to a minimum.

Table VI shows the incidence of toxic effects recorded. The commonest was restlessness, a characteristic disturbance consisting of alertness and relatively increased activity in the evenings coupled with more than usual reluctance to go to bed but not with insomnia. The complaints of dry mouth and thirst are certainly under-estimated because as shown in Table $\mathrm{V}$, the symptoms tended to be virtually exclusive whereas one would have expected them to be coupled. The check list presented to the parents on each occasion included flushing, palpitations, heartburn, fatigue, urinary retention, vomiting, weakness, unsteadiness, dizziness, Parkinsonism, jaundice and confusion but none of these were admitted. 
Table V

Toxic effects, relevant and maximum doses reached, and relationship between the occurrence of toxic effects and the outcome

\begin{tabular}{|c|c|c|c|c|c|c|}
\hline $\begin{array}{l}\text { Case } \\
\text { Number }\end{array}$ & Toxic effects & $\begin{array}{l}\text { Weight } \\
\text { (kg) } \\
\text { (W) }\end{array}$ & $\begin{array}{l}\text { Minimum } \\
\text { dose toxic } \\
\text { (D) }\end{array}$ & $\begin{array}{l}\text { Minimum } \\
\text { dose/weight } \\
\text { (mg/kg) }\end{array}$ & $\begin{array}{l}\text { Maximum } \\
\text { dose reached } \\
\text { (mg) }\end{array}$ & $\begin{array}{l}\text { Maximum } \\
\text { dose } / \text { weight } \\
(\mathrm{mg} / \mathrm{kg})\end{array}$ \\
\hline 1 & Constipation & 18.2 & 35 & 1.92 & 55 & 3.02 \\
\hline \multirow[t]{2}{*}{2} & \multirow{2}{*}{$\begin{array}{l}\text { Nightmares } \\
\text { Headache } \\
\text { Restlessness }\end{array}$} & 18.1 & $\begin{array}{l}50 \\
50\end{array}$ & 2.76 & \multirow[t]{2}{*}{50} & \multirow[t]{2}{*}{2.76} \\
\hline & & 25.0 & 25 & & & \\
\hline 3 & Nightmares & 25.0 & 10 & 0.4 & 10 & 0.4 \\
\hline 4 & & 28.5 & & & 125 & 4.39 \\
\hline 5 & . & 19.5 & - & & 60 & 3.08 \\
\hline 6 & Dry mouth. Thirst & 19.0 & 25 & 1.32 & 60 & 3.16 \\
\hline 7 & Sleepiness & 19.0 & 25 & 1.32 & 60 & 3.16 \\
\hline 8 & Sleepiness. Restlessness & 18.0 & 35 & 1.94 & 85 & 4.72 \\
\hline 9 & Sleepiness & 50.0 & 75 & 1.50 & 15 & 3.00 \\
\hline 10 & Anorexia & 22.0 & 100 & 4.55 & 125 & 5.68 \\
\hline 11 & Thirst. Anorexia & 28.0 & 25 & 0.89 & 85 & 3.04 \\
\hline 12 & Dry Mouth & 27.5 & 85 & 3.09 & 90 & 3.27 \\
\hline 13 - & $\begin{array}{l}\text { Restlessness. } \\
\text { Dry Mouth. Thirst }\end{array}$ & 20.0 & $\begin{array}{l}35 \\
35\end{array}$ & $\begin{array}{l}1.75 \\
1.25\end{array}$ & 75 & 3.75 \\
\hline 14 & & 19.0 & & & 150 & 7.89 \\
\hline 15 & $\begin{array}{l}\text { Dry Mouth } \\
\text { Headache }\end{array}$ & 23.0 & $\begin{array}{l}50 \\
10\end{array}$ & $\begin{array}{l}2.17 \\
0.43\end{array}$ & 100 & 4.35 \\
\hline 16 & Restlessness & 26.0 & 75 & 2.88 & 75 & 2.88 \\
\hline 17 & Thirst & 33.0 & 10 & 0.30 & 75 & 2.27 \\
\hline 18 & $\begin{array}{l}\text { Sweating, Dry mouth. } \\
\text { Thirst } \\
\text { Paraesthesiae }\end{array}$ & $18.0^{\circ}$ & $\begin{array}{l}35 \\
25\end{array}$ & $\begin{array}{l}1.94 \\
1.39\end{array}$ & 55 & 3.06 \\
\hline 19 & . & 15.5 & & & 25 & 1.61 \\
\hline 20 & Thirst & 26.0 & 25 . & 0.96 & 75 & 2.88 \\
\hline 21 & $\begin{array}{l}\text { Thirst } \\
\text { Sleepiness }\end{array}$ & 18.0 & $\begin{array}{l}50 \\
55\end{array}$ & $\begin{array}{l}2.78 \\
3.06\end{array}$ & 55 & 3.06 \\
\hline 22 & $\begin{array}{l}\text { Thirst } \\
\text { Sweating. Restlessness }\end{array}$ & 43.0 & 10 & 0.23 & 130 & 3.02 \\
\hline 23 & & 19.0 & & & 60 & 3.16 \\
\hline 24 & Nausea & 38.0 & 10 & 0.26 & 110 & 2.89 \\
\hline 25 & & 19.0 & & & 35 & 1.84 \\
\hline 26 & . & 20.5 & & & 60 & 2.39 \\
\hline 27. & $\therefore$ & 19.0 & & & 60 & 3.16 \\
\hline
\end{tabular}


(Table V continued)

\begin{tabular}{|c|c|c|c|c|c|c|}
\hline $\begin{array}{c}\text { Case } \\
\text { Number }\end{array}$ & Toxic effects & $\begin{array}{l}\text { Weight } \\
\text { (kg) } \\
\text { (W) }\end{array}$ & $\begin{array}{l}\text { Minimum } \\
\text { dose toxic } \\
\text { (D) }\end{array}$ & $\begin{array}{c}\text { Minimum } \\
\text { dose/weight } \\
(\mathrm{mg} / \mathrm{kg})\end{array}$ & $\begin{array}{c}\text { Maximum } \\
\text { dose reached } \\
(\mathrm{mg})\end{array}$ & $\begin{array}{l}\text { Maximum } \\
\text { dose/weight } \\
(\mathrm{mg} / \mathrm{kg})\end{array}$ \\
\hline 28 & Restlessness & 25.5 & 50 & 1.96 & 50 & 1.96 \\
\hline 29 & Restlessness & 20.5 & 35 & 1.71 & 60 & $: 2.93$ \\
\hline 30 & Anorexia & 17.0 & 35 & 2.06 & 50 & 2.94 \\
\hline 31 & $\begin{array}{l}\text { Dry Mouth } \\
\text { Thirst } \\
\text { Headache }\end{array}$ & 28.0 & $\begin{array}{l}10 \\
10 \\
25\end{array}$ & $\begin{array}{l}0.36 \\
0.89\end{array}$ & 100 & 3.60 \\
\hline 32 & . & 30.0 & . & & 10 & 0.33 \\
\hline 33 & $\begin{array}{l}\text { Restlessness } \\
\text { Thirst }\end{array}$ & 25.0 & $\begin{array}{l}35 \\
50\end{array}$ & $\begin{array}{l}1.40 \\
2.00\end{array}$ & 75 & 3.00 \\
\hline 34 & . & 33.0 & & & 100 & 3.03 \\
\hline 35 & . & 33.0 & & $\therefore$ & 25 . & 0.76 \\
\hline 36 & $\begin{array}{l}\text { Nightmares } \\
\text { Foul taste }\end{array}$ & 27.0 & $\begin{array}{r}25 \\
75\end{array}$ & $\begin{array}{l}0.93 \\
2.78\end{array}$ & 100 & 3.70 \\
\hline 37 & , & 27.0 & $\because$ & & 50 & 1.85 \\
\hline 38 & 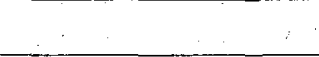 & 22.5 & & . & 75 & 3.33 \\
\hline 39 & 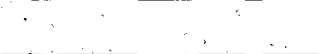 & 27.5 & & $\therefore$ & 75 & 2.73 \\
\hline 40 & & 18.5 & & $\therefore \quad \therefore$ & 35 & 1.89 \\
\hline $41^{\circ}$ & Headache & 19.0 & 10 & 0.53 & 35 & 1.84 \\
\hline 43 & Paraesthesiae & 22.0 & 50 & 2.27 & 75 & 3.41 \\
\hline 44 & $\cdots$ & 37.0 & & & 100 & 2.70 \\
\hline 45 & . & 18.0 & 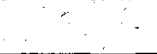 & $\cdots$ & 50 & 2.78 \\
\hline 46 & , & 25.0 & $\therefore$ & $\because$ & 25 & 1.00 \\
\hline 47 & $\begin{array}{l}\text { Nightmares } \\
\text { Dry Mouth }\end{array}$ & 33.0 & $\begin{array}{l}10 \\
25\end{array}$ & $\begin{array}{l}0.30 \\
0.76\end{array}$ & 100 & 3.03 \\
\hline 48 & Constipation & 33.3 & 25 & 0.75 & 100 & 3.00 \\
\hline 49 & $\therefore$ & 20.3 & 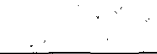 & $\therefore$ & 35 & 1.72 \\
\hline 50 & Restlessness & $22: 0$ & 35 & 1.59 & 75 & 3.41 \\
\hline 51 & Restlessness & 25.0 & 75 & 3.00 & 125 & 5.00 \\
\hline 52 & Anorexia & 28.0 & 85 & 3.04 & 85 & 3.04 \\
\hline 54 & Rash & 21.7 & 25 & 1.15 & $\therefore 25$ & 1.15 \\
\hline 55 & $\begin{array}{l}\text { Anorexia } \\
\text { Sweating. Constipation }\end{array}$ & 25.5 & $\begin{array}{l}50 \\
75 \\
\end{array}$ & $\begin{array}{l}1.96 \\
2.94\end{array}$ & $75^{\circ}$ & 2.94 \\
\hline 56 & Sleepiness & 22.0 & 60 & 2.73 & 100 & 4.55 \\
\hline 57 & Restlessness & 25.0 & 10 & 0.40 & 10 & 0.40 \\
\hline 58 . & & 20.0 & $:^{\prime \prime} \therefore$ & & 10 & 0.50 \\
\hline
\end{tabular}


(Table $\mathrm{V}$ continued)

\begin{tabular}{|c|c|c|c|c|c|c|}
\hline $\begin{array}{c}\text { Case } \\
\text { Number }\end{array}$ & Toxic effects & $\begin{array}{l}\text { Weight } \\
\text { (kg) } \\
\text { (W) }\end{array}$ & $\begin{array}{l}\text { Minimum } \\
\text { dose toxic } \\
\text { (D) }\end{array}$ & $\begin{array}{l}\text { Minumum } \\
\text { dose/weight } \\
\text { (mg/kg) }\end{array}$ & $\begin{array}{c}\text { Maximum } \\
\text { dose reached } \\
(\mathrm{mg})\end{array}$ & $\begin{array}{l}\text { Maximum } \\
\text { dose } / \text { weight } \\
(\mathrm{mg} / \mathrm{kg})\end{array}$ \\
\hline 59 & Anorexia. Nausea & 44.0 & 35 & 0.80 & 135 & 3.07 \\
\hline 60 & & 25.0 & & . & 75 & 3.00 \\
\hline $61^{\circ}$ & Restlessness & 22.2 & 10 & 0.45 & 70 & 3.15 \\
\hline 62 & & $16.0^{\circ}$ & & & 35 & 2.19 \\
\hline 63 & $\begin{array}{l}\text { Anorexia } \\
\text { Dry Mouth } \\
\text { Restlessness. Nausea }\end{array}$ & 36.0 & $\begin{array}{r}35 \\
125\end{array}$ & $\begin{array}{l}0.97 \\
3.47\end{array}$ & 125 & 3.47 \\
\hline 64 & $\ddots$ & 20.0 & & & 75 & 3.75 \\
\hline 65 & & 13.5 & & & 100 & 7.41 \\
\hline
\end{tabular}

Table VI

Incidence of toxic effects recorded

\begin{tabular}{l|c|l|c|l|c}
\hline \multicolumn{1}{r|}{ Incidence } & Cases & \multicolumn{1}{c|}{ Incidence } & Cases & \multicolumn{1}{c}{ Incidence } & Cases \\
\hline Restlessness & 13 & Drowsiness & 5 & Nightmares & 4 \\
\hline Dry Mouth & 8 & Headache & 4 & Paraesthesia & 2 \\
\hline Thirst & 10 & Constipation & 3 & Foul taste & 1 \\
\hline Anorexia & 7 & Sweating & 3 & Rash & 1 \\
\hline Nausea & 3 & & & & \\
\hline
\end{tabular}

\section{Discussion}

The causation of enuresis is multiple (Apley and MacKeith 1968) and there is certainly a constitutional factor. The sympton may occur as a complication of neurological diseases involving cerebral or peripheral nerve degeneration like arteriosclerosis and diabetes or other organic disease, but usually only as an incidental symptom. The great majority of sufferers have a simple syndrome occurring in otherwise good health and with no obvious evidence of disease. In such children incontinence may be attributed to laziness, polyuria, urinary infection, a small bladder, impaired bladder control or to deep sleep. "Laziness" is merely an expression of parental irritation and, the acceleration of school progress and improvement in home behaviour often seen after successful treatment suggests that psychological disturbances derive from the symptom more often than they cause it. Nevertheless, anxiety and emotional disorder may also be important aetiologically in enuresis. Polyuria is probably unimportant in itself, the problem being that the child does not wake to micturate rather than he does it too often. The evidence regarding sleep is conflicting. Electro-enephalographic studies have shown that enuresis occurs both in deep sleep (Gastaut and Broughton 1965, Pierce et al 1961) and in light 
sleep (Ditman and Blain 1955, Bental 1961 and Schiff 1965). One might suggest that the truly significant fact that sleep at whatever level is undisturbed by sufficient bladder distention to evoke reflex evacuation. If this is the case, any beneficial effect of the tricyclic drugs on enuresis is unlikely to be due to their suppression of rapid eye movement (REM) sleep.

In normal micturition, contraction of the detrusor induces opening of the bladder neck immediately preceded by relaxation of the pelvic floor and external sphincter (Tanagho, Hutch ànd Miller 1966). The process is reflex and normally occurs when its inhibition is voluntary inhibited. The reflex may be initiated by afferent bombardment, as occurs in severe urinary infections (Shuttleworth 1970), thus producing urgency incontinence like that of the enuretic's daytime accidents. However, in these children urinary infection is not an adequate explanation. In them, emptying of the bladder occurs before distention causes waking or even daytime awareness, possibly because of a defect in conduction above the reflex level, perhaps in the reticular formation. The tricyclic drugs might act at this level by virtue of their anti-cholinergic and andrenolytic effects. An anti-cholinergic effect has been shown to be useful by Leys (1956) who showed benefit with propantheline bromide. Electrical enuresis alarms are also beneficial, and the work of Scholander (1968) showing a potentiation of drug treatment by the alarm is consistent. It is postulated that primary enuresis is due to delay in development of inhibition of micturition during sleep and that in secondary enuretics other causes lead to interference with precariously established controls.

Considerable variation in reported incidence of enuresis exists (Bloomfield and Douglas 1956, MacKeith 1961, Pringle, Butler and Davie 1966) but between the ages of 5 and 15, ninety per cent of enuretics might be expected to achieve continence spontaneously, at a rate of about 9 per cent per year. To achieve continence in 44 per cent within 3 to 6 months is therefore a definite improvement but it is little better than the results of Dische (1971) without the use of drugs at all. However, these patients are not necessarily comparable with hers. For example, seventy per cent of these children had had treatment with tricyclic drugs alone, whereas only 44 per cent of hers had had previous treatment of any sort. Lake (1968) has described a double blind comparison of notrtiptyline with placebo and found the drug to have a beneficial effect, the management of both groups being similar to the present one apart from the addition of imposed. fluid restriction, and the use of only $25 \mathrm{mg}$ of nortriptyline each night. Improvement was measured by any reduction of frequency of incontinence and no account of size was taken in spite of an age range between 5 and 12 years. One complaint of a toxic effect was made in 108 periods of treatment with the active drug. His results demonstrate the potential of the treatment but no more, the disability caused by enuresis not being appreciably, affected by a mere reduction in its frequency.

Forsythe and Merrett (1969) made a comparison between $50 \mathrm{mg}$ imipramine and $25 \mathrm{mg}$ nortriptyline in 298 children aged between 4 years and 15 years. Again, no account of size was taken and all children got the same dose. The authors make the, point that "patients are not the slightest bit interested in a significant reduction in the number of wet nights" and doubted whether they could have persuaded the parents to continue treatment for a further four to eight weeks after the initial eight weeks of the trial. Indeed they suffered a high withdrawal rate which contrasted with the present trial which lost only 4 out of 63 before completion. They obtained only between 1 and 2 per cent complete cure but concluded that both drugs were significantly better than placebo. 
Maxwell and Seldrup (1971) in a general practice trial of imipramine against a placebo found the drug significantly superior in doses up to $50 \mathrm{mg}$ but, again, they took improvement to mean a reduction in number of wet nights and did not aim for continence. They found a therapeutic range of $0.9 \mathrm{mg} / \mathrm{kg}$ to $1.5 \mathrm{mg} / \mathrm{kg}$ but derived their ratio by calculation from the ages of the children and not by weighing them.

As expected, in view of the work of Alexanderson, Price-Evans and Sjoqvist (1969) and of Hammer, Idestron and Sjoqvist (1967), there is a poor correlation between the dose given in $\mathrm{mg}$ per $\mathrm{kg}$ body weight and the serum level achieved. This indicates that with nortriptyline, in children as in adults, the variability of metabolism is such that the serum level of the drug cannot be predicted from the amount consumed and the body weight. However, in this trial the dose was a better predictor of outcome than was the blood level.

\section{Primary and secondary enuretics}

The lack of any difference in response between primary and secondary enuretics was surprising. The latter group consisted of those 17 children who had formerly achieved continence at night for at least a year without interruption. It had been expected that they would do less well because they were likely to have an additional factor to the assumed retardation of control of development of primary enuretics. It may be that the symptom responds to treatment whenever the balance between adverse and favourable factors is disturbed in the right direction.

\section{Toxic effects}

The tricyclic drugs do have anti-cholinergic and adrenolytic effects (Ban 1969) but not very powerful ones and there was no correlation here between toxic effects and outcome.

The anti-cholinergic side effects of dry mouth and thirst were common but were tolerated well and are tolerable if the treatment is effective. The other common side effect was alert restlessness in the evenings which occurred in 13 patients. Ban suggests that the tricyclic drugs have a central effect of sensitization to adrenergic effects, in particular the potentiation of adrenaline. The effect on the reticular formation and arousal reaction is obscure and, though the tricyclic drugs are generally thought to have a depressant effect, this may not be so in the presence of normal catecholamine stores. The findings here certainly suggest an arousal effect but it does not necessarily follow that any beneficial effects would be comparable with the results of treatment with amphetamines. The lack of association between the restlessness of these 13 children and any tendency to insomnia would support a brain-stem as opposed to a cortical effect. Four of them achieved continence, proportionately the same as in the trial overall.

The caution exercised to ensure toxic effects did not occur undetected and the constant reminders to the parents may have exaggerated the frequency of complaints. It is not possible to show a significant statistical relation to dosage or to dose/weight ratio (Note: Table 7 contains results of 62 estimations of serum nortriptyline but some of these are repeats and only 49 children were tested). Symptoms were usually minor and in only 2 cases was treatment interrupted because of "drug" effects. The primary intention 
Táble Vir

Results of 65 estimations of sérum nortriptyline levels

\begin{tabular}{|c|c|c|c|c|c|}
\hline $\begin{array}{l}\text { Original } \\
\text { heart } \\
\text { rate }\end{array}$ & $\begin{array}{l}\text { Change in } \\
\text { heart rate } \\
\text { in beats } \\
\text { per minute }\end{array}$ & $\begin{array}{l}\text { Percentage } \\
\text { change in } \\
\text { heart rate }\end{array}$ & $\begin{array}{l}\text { Dose in } \\
\mathrm{mg}\end{array}$ & $\begin{array}{l}\text { Dose/weight } \\
\mathrm{ratio} \text { in } \\
\mathrm{mg} / \mathrm{kg}\end{array}$ & $\begin{array}{c}\text { Blood level } \\
\text { in } \\
\mathrm{mg} / \mathrm{ml}\end{array}$ \\
\hline 93 & - & - & 70 & 3.18 & 132 \\
\hline $100 \cdots$ & 25 & 25.0 & 55 & $3.05 \ldots$ & 115 \\
\hline 93 & - & - & 65 & 2.95 & 44 \\
\hline 63 & 25 & 39.6 & 75 & 3.00 & 43 \\
\hline 88 & 32 & 36.4 & 75 & 2.94 & 122 \\
\hline 93 & 22 & 23.7 & 75 & 3.00 & 89 \\
\hline 93 & 7 & 7.8 & 60 & 3.00 & 83 \\
\hline 75 & 25 & 33.3 & 90 & 3.27 & 112 \\
\hline 88 & - & - & 50 & 2.77 & 169 \\
\hline 88 & $: 12$ & 13.6 & 55 & 3.05 & 67 \\
\hline 93 & 32 & 34.4 & 50 & 2.43 & $198^{\circ}$ \\
\hline 75 & 4. & 5.3 & 50 & 2.94 & $=23$ \\
\hline 75 & 25 & 33.3 & 50 & 1.85 & 38 \\
\hline 79 & 21 & 26.6 & .35 & 1.89 & 90 \\
\hline 75 & 25 & 33.3 & 30 & 3.27 & 109 \\
\hline 93 & 14 & 15.0 & 35 & 1.84 & 32 \\
\hline 83 & 17 & $20.5^{-}$ & 35 & 1.84 & 106 \\
\hline 115 & 21 & 18.3 & 35 & 2.18 & 53 \\
\hline 93 & 22 & 23.7 & 25 & 1.28 & 100 \\
\hline 71 & 36 & 50.7 & $25 \cdots$ & 1.31 & $\therefore \quad 60$ \\
\hline 115 & -8 & -7.0 & 25 & 1.38 & 72 \\
\hline 75 & .32 & 42.7 & 25 & .91 & 95 \\
\hline 93 & 22 & 23.7 & 25 & 1.00 & $35^{-}$ \\
\hline 79 & 14 & 17.7 & 25 & -1.85 & 43 \\
\hline 100 & - & - & 10 & .40 & 30 \\
\hline 75 & 25 & 33.3 & 60 & 3.15 & 256 \\
\hline 115 & - & - & 60 & 3.33 & 73 \\
\hline 68 & 47 & 69.1 & 85 & 3.03 & $\therefore 151$ \\
\hline 71 & 36 & 50.7 & 75 & 288 & 317 \\
\hline 93 & 14 & 15.0 & 60 & 3.15 & 145 \\
\hline 71 & 22 & 31.0 & 100 & 2.63 & 91 \\
\hline
\end{tabular}


of Steady-State Serum Levels

(Table VII continued)

\begin{tabular}{|c|c|c|c|c|c|}
\hline $\begin{array}{c}\text { Original } \\
\text { heart } \\
\text { rate }\end{array}$ & $\begin{array}{l}\text { Change in } \\
\text { heart rate } \\
\text { in beats } \\
\text { per minute }\end{array}$ & $\begin{array}{l}\text { Percentage } \\
\text { change in } \\
\text { heart rate }\end{array}$ & $\begin{array}{l}\text { Dose in } \\
\mathrm{mg}\end{array}$ & $\begin{array}{l}\text { Dose/weight } \\
\mathrm{ratio} \text { in } \\
\mathrm{mg} / \mathrm{kg}\end{array}$ & $\begin{array}{c}\text { Blood level } \\
\text { in } \\
\mathrm{mg} / \mathrm{ml}\end{array}$ \\
\hline 93 & 14 & 15.0 & 85 & 3.03 & 92 \\
\hline 68 & 32 & 47.1 & $80^{-}$ & 2.96 & 90 \\
\hline 83 & 17 & 20.5 & 100 & 2.10 & 210 \\
\hline 83 & 5 & 6.0 & 100 & 3.03 & 20 \\
\hline 75 & 25 & 33.3 & 100 & 3.98 & 89 \\
\hline 100 & 25 & 25.0 & 65 & 2.95 & 42 \\
\hline 107 & -14 & -13.1 & 135 & 3.06 & 68 \\
\hline 93 & 7 & 7.5 & 55 & 2.97 & 157 \\
\hline 93 & 22 & 23.7 & 75 & 3.75 & 127 \\
\hline 100 & - & - & 70 & 3.18 & 53 \\
\hline 100 & 7 & 7.0 & 60 & 3.00 & 90 \\
\hline 100 & 15 & 15.0 & 60 & 3.15 & 40 \\
\hline 93 & - & - & 70 & 3.04 & 48 \\
\hline 75 & 13 & 17.3 & 75 & 2.88 & 91 \\
\hline 88 & 27 & 30.7 & 35 & 1.94 & 141 \\
\hline 93 & 7 & 7.5 & 50 & 1.96 & 94 \\
\hline 88 & 27 & 30.7 & 75 & 3.00 & 141 \\
\hline 107 & 8 & 7.5 & 75 & 3.33 & 150 \\
\hline 68 & 32 & 47.1 & 75 & 2.72 & 194 \\
\hline 88 & 5 & 5.7 & 125 & 4.35 & 174 \\
\hline 100 & 7 & 7.0 & 125 & 5.68 & .164 \\
\hline 83 & 24 & 28.9 & 125 & 3.47 & 110 \\
\hline 115 & 10 & 8.7 & 75 & 4.16 & 174 \\
\hline 115 & -8 & -7.0 & 150 & 3.00 & 202 \\
\hline 88 & 5 & 5.7 & 85 & 2.98 & 88 \\
\hline 75 & 32 & 42.7 & 60 & 3.15 & 310 \\
\hline 71 & 44 & 62.0 & 60 & 3.15 & 89 \\
\hline 68 & 47 & 69.1 & 85 & 3.03 & 30 \\
\hline 71 & 29 & 40.8 & 125 & 2.90 & 164 \\
\hline 63 . & -10 & -15.9 & 125 & 5.00 & 97 \\
\hline 83 & 32 & 38.6 & 110 & 3.05 & 85 \\
\hline
\end{tabular}


of the electrocardiography was to watch for known toxic effects of the drug but these failed to appear, apart from quite frequent inversions of T 3. In children this is not uncommon and in any case the inversions proved unstable both on respiration and from time to time.

It was concluded that no significant effects on electrical conduction within the heart were detectable at the dose levels employed. On the other hand Steele, O'Duffy and Brown (1967) have shown that sinus tachycardia occurs in mild cases of poisoning with imipramine and with amitriptyline, without arrhythmias. Heart rates changed between slowing of 14 beats per minute and acceleration of 47 beats per minute from base levels of 63 to 115 , giving an average increase of 17.6 beats per minute on all children tested when blood level of nortriptyline was known (Table VII). The correlation between change in heart rate and dosage level of the drug was not expected to be high because of the large number of uncontrolled factors such as psychological status, variable fatigue etc. and the correlation between change of heart rate, percentage change of heart rate and dose or dose/weight ratio were about minus 0.18 to plus 0.18 but the correlation between change of heart rate and blood levels of the drug did reach 0.63 . These findings tend to confirm a stimulating effect on the sino-atrial node.

\section{Conclusions}

This study seems to show that beneficial effects of nortriptyline in enuresis can be obtained by using larger doses. It demonstrates that there are therapeutic ranges of $25 \mathrm{mg}$ to $100 \mathrm{mg}$ o.n. or $1.5 \mathrm{mg} / \mathrm{kg}$ to $3.5 \mathrm{mg} / \mathrm{kg}$ but the expected closer correlation between results and actual blood level has not been demonstrated convincingly. In this range complete control of enuresis can be obtained, at least for a short period, in over 40 per cent of subjects.

The treatment is, of course, complimentary to other methods of general management and so-called conditioning. Its main draw-back is the problem of toxicity. Enuresis is, at least on a superficial view, merely an irritating symptom so that toxic effects, particularly in children, are to be avoided wherever possible but, under the conditions of this study, no serious damage was known to have occurred and it was necessary to stop treatment in only one case.

\section{Acknowledgements}

Thanks are due to the patients and their families, to the Computer Centre, B.A.O.R., Royal Air Force Hospital, Wegberg, Royal Air Force Transport Command and to Mr. Robin Braithwaite of Guys Poisons Centre.

Abrams, A. L. (1964). Amer. J. Psychiat. 121, 87.

\section{REFERENCES}

Agarwala, S. and Heycock, J. B. (1968). Brit. J. clin. Pract. 22, 296.

Alderton, H. R. (1965). Canad. psychiat. Ass. J. 10, 141.

Alexanderson, B., Price Evans, D. A. and Sjoqvist, F. (1969). Brit. med. J. iv, 764.

ApleY, J. and MacKerry, R. (1968). The Child and His Symptoms. 2nd ed. Blackwe Scientific Publications. Oxford.

Asberg, M., Cronholm, B., Sjopvist, F. and Tuck, D. (1971) Brit. med. J. iii, 331 .

Ban, T. A. (1969). Psychopharmacology. Williams \& Wilkins. Baltimore. P.274-276.

BeNTAL, E. (1961). J. psychosom. Res. 5, 116.

Bloomfield, J. M. and Douglas, J. W. B. (1956). Acta paediat. (Uppsala) 48, Suppl. 118.

Brackenbridge, R. G., Peters, T. J. and Watson, Joyce M (1968). Scot. med. J. 13, 208.

Braithwaite, R. A. and Widdop, B. (1971). Clin. chim. Acta. 35, 461.

Connelly, J. F. and Venables, A. W. (1961). Med. J. Aust. 1, 108.

Dische, Sylvia (1971). Brit. med. J. ii, 33.

Ditman, K. S. and Blain, K. A. (1955). Amer. J. Psychiat. 111, 913.

.Fisher, G. W., Murray, F., Walley, M. R. and Klloh, L. G. (1963). Amer. J. ment. Defic. $67,536$.

Forsythe, W. I. and MerRETT, J. D. (1969). Brit. J. clin. Pract. 23, 5. 
Gastaut, H. and Broughton, R. J. (1965). Recent Advances in Biological Psychiatry. Vol. 7. Plenum Press. New York, P.197.

GiLes, H. M. (1963). Brit. med. J. ii, 844.

GraM, L. F. and OVER, K. F. (1972). Brit. med. $J$. i, 463.

Hammer, W., IdesTrom, C. M. and Sjoqvist, F. (1967). Excerpta Med. Internat. Congr. Ser. 122, 301.

ICE, J. F., DAus, A. T. and Smith, R. (1966). Proc. 4th World Congr. Psychiatry. Madrid. Excerpta. Med. Internat. Cong. Ser. 117, Abstract No. 576.

Kelly, H. G., FAy. J. E. and Laverty, S. G. (1963). Canad. med. Ass. J. 89, 546.

KRISTIANSEN, E. S. (1961). Act. psychiat. scand. 36, 427.

LAKE, B. (1968). Med. J. Aust. 1, 582.

LEYS, D. (1956). Brit. med. J. i, 549.

MacKeith, R. C. (1961). Guy's Hospital Gazette 75, 341.

Maclean, R. E. (1960). Amer. J. Psyehiat. 117, 551.

Mariuz, M. J. and WAlters, C. J. (1963). Amer. J. Psychiat. 120, 597.

MaXwell, C. and Seldrup, J. (1971). Arzeimittel-Forsch (Drug Res.) 21, 1352.

MEADOW, R. (1970). Brit. med. J. iv, 787.

MiLNer, G. and Hills, N. F. (1968). Med. J. Aust. i, 943.

NOACK, C. H. (1964). Med. J. Aust. 1, 191.

Peirce, C. M., Whitman, R. M., MaAs, J. W. and Gray, M. L. (1961), Arch. gen. Psychiat. 4, 166.

Pringle, M. L. K., Butler, N. R. and DAVIE, R. (1966). 11,000 Seven Year-Olds. Longmans. London. P.75.

SCHIFF, S. K. (1965). J. nerv. ment. Dis. 140, 397.

SCHOLANDER, T. (1968). Lakartidningen. Vol. 165, NR46.

SHUTTLEWORTH, K. E. D. (1970). Brit. med. J. iv, 727.

SMith, E. H. and GonZALES, R. (1967). Amer. J. ment. Defic. 71, 825.

STEEL, C. M., O'DuffY, J. and Brown, S. S. (1967). Brit. med. J. iii, 663.

Stevenson. I. H., Browning, Margaret, Crooks, J. and O'MALley, K. (1972). Brit. med. J. iv, 322.

Tanagho, E. M., Hutch, J. A. and Miller, E. E. (1966). Brit. J. Urol. 38, 435.

Thomsen, W., ReID, W. B. and Hebeler, J. (1967). Dis. nerv. Syst. 28, 167.

Trefrert, D. A. (1964). Amer. J. Psychiat. 121, 87.

WALTER, C. J. S. (1971). Proc. roy. Soc. Med. 64, 282.

YODFAT, Y. (1966). Lancet i, 368.

JounG, G. C. (1969). Brit. J. Hosp. Med. 2, 628.

MAJOR-GENERAL J. J. MAGNER, C.B., M.C.

The sad news of the death of Jerry. Magner prompts me to write a few personal reminiscences.

We first met when with the Egyptian Army in 1923 when he succeeded me as S.M.O. in Kassala Province, after I had broken my collar bone playing polo and had to go to Khartoum for treatment.

Jerry was very popular and extremely likeable. By nature slow and deliberate, he had a quiet Irish humour. I remember when on camel trek together it was a supreme effort to get him to rise and take to the road at dawn.

Our next meeting was in Khartoum in 1924 when the Sudanese rebellion broke out after Sir Lee Stack the Governor General had been murdered in Cairo. A chance meeting on that occasion I always felt may have saved my life. Carlyle our S.M.O. had just been murdered in the Military Hospital and just as I was making my way out of the building, I was stopped and warned of the danger by Magner. I promptly took his advice. The rebel officers were eventually shot after a court martial and Jerry had the unpleasant duty of attending the shooting.

It was another 16 years after that when we met again at Leeds where Magner was Commanding the R.A.M.C. Depot opened there during the war. In the intervening years he had qualified as a radiologist and on his retirement after being promoted to D.D.M.S. of a Command he took up the Directorship of Civilian Mass Miniature Radiography in the Dublin area.

With his beetling eyebrows Magner had a forbidding aspect which hid his kindness of heart. To his charming wife we express our deepest sympathy. Sir NEIL CanTLIE 